\title{
Titanium Dioxide Nanoparticles Catalyzed Synthesis of Hantzsch Esters and Polyhydroquinoline Derivatives
}

\author{
Mahmood TAJBAKHSH ${ }^{1, *}$, Ehsan ALAEE ${ }^{2}$, Heshmatollah ALINEZHAD ${ }^{1}$, Mohammad KHANIAN ${ }^{1}$, \\ Fatemeh JAHANI ${ }^{1}$, Samad KHAKSAR ${ }^{3}$, Parizad REZAEE ${ }^{1}$, Mahgol TAJBAKHSH ${ }^{1}$ \\ ${ }^{1}$ Department of Organic Chemistry, Faculty of Chemistry, University of Mazandaran, Babolsar 47415, Iran \\ ${ }^{2}$ Gorgan Medical University, Gorgan, Iran \\ ${ }^{3}$ Chemistry Department, Islamic Azad University, Ayatollah Amoli Branch, Amol P.O. Box 678, Iran
}

\begin{abstract}
Dihydropyridine and polyhydroquinoline derivatives have been prepared efficiently in a one-pot synthesis via Hantzsch condensation using nanosized titanium dioxide as a heterogeneous catalyst. The present methodology offers several advantages such as excellent yields, short reaction times (30-120 min), environmentally benign, and mild reaction conditions. The catalyst can be readily separated from the reaction products and recovered in excellent purity for direct reuse.
\end{abstract}

Key words: titanium dioxide nanoparticles; Hantzsch reaction; 1,4-dihydropyridine; polyhydroquinoline CLC number: O643 Document code: A

Received 25 March 2012. Accepted 14 June 2012.

*Corresponding author. Fax: +98-11253-42302; E-mail: tajbaksh@umz.ac.ir

This work was supported by the Research Council of the University of Mazandaran.

English edition available online at Elsevier ScienceDirect (http://www.sciencedirect.com/science/journal/18722067).

Heterocyclic chemistry is an inexhaustible resource of novel compounds [1]. Heterocycles play a major part in biochemical processes and are also side groups of the most typical and essential constituents of living cells. Other important practical applications of these compounds can also be cited, for instance, their use as additives and modifiers in a wide variety of industries including cosmetics, reprography, information storage, plastics, solvents, antioxidants, and vulcanization accelerators. Among N-containing heterocycles, 1,4-dihydropyridines (1,4-DHPs) attracted immense attention because of their wide pharmaceutical activity range acting, for example, as vasodilator, bronchodilator, antiatherosclerotic, antitumour, antidiabetic, geroprotective, and hepatoprotective agents [2-4]. These examples clearly demonstrate the remarkable potential of 1,4-DHP derivatives as a source of valuable drugs. Preparation of 1,4-DHP was first reported by Hantzsch in 1882 via the reaction of aldehydes with ethyl acetoacetate and ammonia in acetic acid or by refluxing in alcohols [5]. Recently, a number of modified methods have been developed [6]. Other procedures comprise the utilization of microwaves [7-9], ionic liquids [10], high temperatures [11-18], TMSCl-NaI [19], $\mathrm{InCl}_{3}$ [20], I $\mathrm{I}_{2}$ [21], $\mathrm{SiO}_{2} / \mathrm{NaHSO}_{4}$ [22], $\mathrm{SiO}_{2} / \mathrm{HClO}_{4}$ [23], CAN [24], Na- and Cs-Norit carbons [25], fermenting Baker's yeast [26], organocatalysts [27], metal triflates [28], Co NPs [29], and fluorinated solvents [30].

Although many of these methods are effective it is still necessary to continue the search for a better catalyst for the synthesis of 1,4-DHP and polyhydroquinolines in terms of operational simplicity, reusability, economic viability, and greater selectivity.

Heterogeneous catalysts are advantageous over conventional homogeneous catalysts as they can be easily recovered from the reaction mixture by simple filtration and can be reused after activation, thereby making the process economically viable. Khadikar et al. [7] reported that nanocrystalline titanium (IV) oxide efficiently catalyzes the conjugate 1,4-addition of indoles to $\alpha, \beta$-unsaturated ketones and 1,2-addition of $\mathrm{Me}_{3} \mathrm{SiCN}$ to carbonyl compounds. They demonstrated the efficiency of nano titanium dioxide and attributed it to the enhanced acidic sites and surface area.

In continuation of our effort towards the development of efficient synthetic procedures for multicomponent reactions [30-33], we turned our attention towards the synthesis of 1,4-DHPs and polyhydroquinolines. We report herein a practical synthesis of these compounds using a catalytic amount of titanium dioxide nanoparticles (Schemes 1 and 2).

\section{Experimental}

Starting materials used in the reactions were procured from Aldrich or Merck Chemical Co. Scanning electron microscopy (SEM) images were taken with a CAM- 


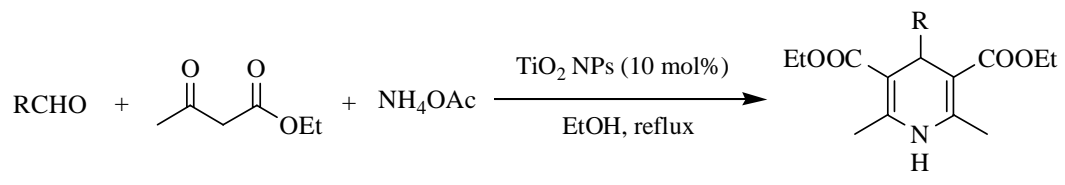

Scheme 1. One-pot synthesis of 1,4-DHPs. NPs-nanoparticles.

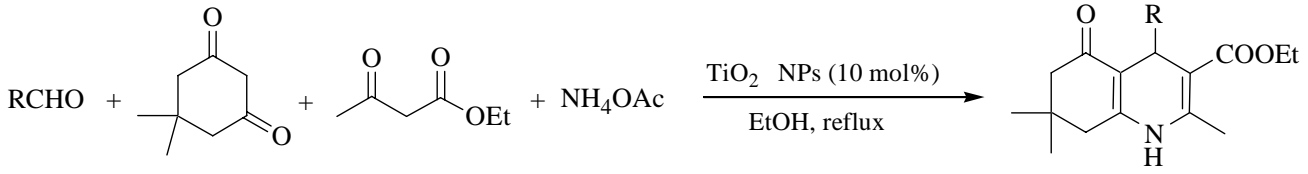

Scheme 2. One-pot synthesis of polyhydroquinoline derivatives.

Scan-MV2300 instrument (England). Atomic force microscopy (AFM) images were recorded by a Nanoserf easyScan 2 flex AFM instrument. Surface area and pore size analysis (BET) were carried out with Belsorp-mini instrument. X-ray powder diffraction (XRD) patterns of the PIs were recorded with an X-ray diffractometer (XRD, GBC MMA Instrument) with Be-filtered $\mathrm{Cu} K_{\alpha}$ radiation. Melting points (mp) were determined on a Thermo Scientific IA9200 instrument and are uncorrected.

\subsection{Synthesis of $1,4-D H P s$}

A mixture of aldehyde (1 mmol), ethyl acetoacetate (2 mmol), ammonium acetate (2 mmol), and titanium dioxide nanoparticles (10 mol\%) was stirred in ethanol $(2 \mathrm{ml})$ at 80 ${ }^{\circ} \mathrm{C}$. The progress of the reaction was checked by TLC. After completion, the reaction mixture was filtered off to separate the catalyst. The solvent was evaporated under reduced pressure to yield the crude product, which was then purified by recrystallization from hot ethanol and water to afford pure 1,4-DHPs.

\subsection{Synthesis of polyhydroquinoline derivatives}

A mixture of aldehyde (1 mmol), ethyl acetoacetate (1 mmol), 5,5-dimethyl-1,3-cyclohexanedione (1 mmol), ammonium acetate $(2 \mathrm{mmol})$, and titanium dioxide nanoparticles $(10 \mathrm{~mol} \%)$ was stirred in ethanol $(2 \mathrm{ml})$ at $80{ }^{\circ} \mathrm{C}$. The progress of the reaction was checked by TLC. After completion, the reaction mixture was filtered off to separate the catalyst. The ethanol was evaporated under reduced pressure to yield the crude product, which was then purified by recrystallization from hot ethanol and water to afford pure polyhydroquinolines.

All the products were characterized through mp, ${ }^{1} \mathrm{H}$ and ${ }^{13} \mathrm{C}$ NMR, and by comparison with authentic samples reported in the literature.

2,6-Dimethyl-4-phenyl-1,4-dihydro-pyridine-3,5-dicarboxylic acid diethyl ester (Table 1 , entry 1). mp: $157-157^{\circ} \mathrm{C}$;
IR $\left(\mathrm{KBr}, \mathrm{cm}^{-1}\right)$ 3342, 1689, 1651, 1491, 1218, 1127, 704. ${ }^{1} \mathrm{H}$ NMR (400 MHz, $\mathrm{CDCl}_{3}$ ): $\delta 1.24$ (t, $\left.J=7.2 \mathrm{~Hz}, 6 \mathrm{H}\right), 2.34$ (s, 6H), 4.06-4.16 (m, 4H), 5.00 (s, 1H), 5.79 (brs, 1H, NH), 7.12-7.16 (m, 1H), 7.2-7.31 (m, 5H); ${ }^{13} \mathrm{C}$ NMR (100 MHz, $\left.\mathrm{CDCl}_{3}\right): \delta 14.25,19.55,39.63,59.73,104.13,126.10$, 127.83, 128.00, 143.92, 147.78, 167.68.

2,6-Dimethyl-4-(4-nitro-phenyl)-1,4-dihydro-pyridine-3, 5-dicarboxylic acid diethyl ester (Table 1, entry 6). mp: 128-130 ${ }^{\circ} \mathrm{C}$; IR (KBr, cm ${ }^{-1}$ ) 3326, 1694, 1646, 1523, 1346, 1218, 1116, 704. ${ }^{1} \mathrm{H}$ NMR (400 MHz, $\left.\mathrm{CDCl}_{3}\right): \delta 1.22(\mathrm{t}, J=$ $7.2 \mathrm{~Hz}, 6 \mathrm{H}$ ), 2.37 (s, 6H), 4.06-4.13 (m, 4H), 5.10 (s, 1H), 5.80 (brs, $1 \mathrm{H}, \mathrm{NH}), 7.46$ (d, $J=8.7 \mathrm{~Hz}, 2 \mathrm{H}), 8.09$ (d, $J=8.7$ $\mathrm{Hz}, 2 \mathrm{H}) ;{ }^{13} \mathrm{C}$ NMR (100 MHz, $\left.\mathrm{CDCl}_{3}\right): \delta 14.27,19.67$, $40.14,60.01,103.21,123.30,128.91,144.63,146.34$, 155.10, 167.06 .

2,6-Dimethyl-4-(4-methoxy-phenyl)-1,4-dihydro-pyridine3,5-dicarboxylic acid diethyl ester (Table 1, entry 7). mp: 160-162 ${ }^{\circ} \mathrm{C}$; IR $\left(\mathrm{KBr}, \mathrm{cm}^{-1}\right)$ 3342, 2983, 1694, 1491. ${ }^{1} \mathrm{H}$ NMR (400 MHz, $\left.\mathrm{CDCl}_{3}\right): \delta 1.23(\mathrm{t}, J=7.2 \mathrm{~Hz}, 6 \mathrm{H}), 2.33$ (s, 6H), 3.76 (s, 3H), 4.04-4.16 (m, 4H), 4.94 (s, 1H), 5.70 (brs, 1H, NH), 6.76 (d, $J=8.6 \mathrm{~Hz}, 2 \mathrm{H}), 7.20$ (d, $J=8.6 \mathrm{~Hz}$, $2 \mathrm{H}) ;{ }^{13} \mathrm{C}$ NMR (100 MHz, $\left.\mathrm{CDCl}_{3}\right): \delta 14.30,19.60,38.74$, $55.14,59.71,104.40,113.18,128.97,140.34,143.58$, 157.87, 167.71 .

2,6-Dimethyl-4-(4-cyano-phenyl)-1,4-dihydro-pyridine3,5-dicarboxylic acid diethyl ester (Table 1, entry 10). mp: 141-142 ${ }^{\circ} \mathrm{C}$; IR (KBr, cm ${ }^{-1}$ ) 3331, 2983, 2234, 1694, 1485, 1047. ${ }^{1} \mathrm{H}$ NMR (400 MHz, $\left.\mathrm{CDCl}_{3}\right): \delta 1.21(\mathrm{t}, J=7.2 \mathrm{~Hz}$, $6 \mathrm{H}), 2.35$ (s, 6H), 4.03-4.15 (m, 4H), 5.04 (s, 1H), 5.80 (brs, 1H, NH), 7.40 (d, $J=8.2 \mathrm{~Hz}, 2 \mathrm{H}), 7.50$ (d, $J=8.2 \mathrm{~Hz}$, $2 \mathrm{H}) ;{ }^{13} \mathrm{C}$ NMR (100 MHz, $\mathrm{CDCl}_{3}$ ): $\delta 14.25,19.56,40.25$, $59.95,103.20,109.70,119.31,128.90,131.82,144.63$, 153.09, 167.16 .

2,7,7-Trimethyl-5-oxo-4-phenyl-1,4,4a,5,6,7,8,8a-octahydro-quinoline-3-carboxylic acid ethyl ester (Table 2, entry 1). mp: 201-203 ${ }^{\circ} \mathrm{C}$; IR (KBr, $\mathrm{cm}^{-1}$ ) 3275, 3080, 2963, 1700, 1610. ${ }^{1} \mathrm{H}$ NMR (400 MHz, $\mathrm{CDCl}_{3}$ ): $\delta 0.94$ (s, 3H), 1.08 (s, 3H), 1.20 (t, $J=7.1 \mathrm{~Hz}, 3 \mathrm{H}), 2.14-2.34$ (m, 4H), 2.36 (s, 3H), 4.07 (q, $J=7.1 \mathrm{~Hz}, 2 \mathrm{H}), 5.06$ (s, 1H), 6.61 
(brs, 1H, NH), 7.09-7.33 (m, 5H); ${ }^{13} \mathrm{C}$ NMR (100 MHz, $\left.\mathrm{CDCl}_{3}\right): \delta 14.21,19.34,27.14,29.44,32.70,36.60,40.90$, 50.73, 59.08, 106.05, 112.08, 126.03, 127.90, 128.01, 143.60, 147.06, 148.50, 167.50, 195.66.

4-(4-Chloro-phenyl)-2,7,7-trimethyl-5-oxo-1,4,4a,5,6,7,8, 8aoctahydro-quinoline-3-carboxylic acid ethyl ester (Table 2, entry 4). mp: $244-245{ }^{\circ} \mathrm{C}$; IR ( $\left.\mathrm{KBr}, \mathrm{cm}^{-1}\right) 3275,3196$, 3080, 2963, 1711, 1645, 1605. ${ }^{1} \mathrm{H}$ NMR (400 MHz, $\mathrm{CDCl}_{3}$ ): $\delta 0.94(\mathrm{~s}, 3 \mathrm{H}), 1.08(\mathrm{~s}, 3 \mathrm{H}), 1.19(\mathrm{t}, J=7.1 \mathrm{~Hz}, 3 \mathrm{H})$, 2.14-2.36 (m, 4H), 2.38 (s, 3H), 4.07 (q, $J=7.2 \mathrm{~Hz}, 2 \mathrm{H}$ ), 5.04 (s, 1H), 6.12 (brs, 1H, NH), 7.16-7.18; ${ }^{13} \mathrm{C}$ NMR (100 $\left.\mathrm{MHz}, \mathrm{CDCl}_{3}\right): \delta 14.21,19.46,27.11,29.43,32.72,36.21$, 41.10, 50.66, 59.92, 105.76, 111.90, 128.00, 129.45, 131.6, 143.61, 145.56, 148.12, 167.22, 195.50.

4-(4-Methoxy-phenyl)-2,7,7-trimethyl-5-oxo-1,4,4a,5,6,7, 8,8aoctahydro-quinoline-3-carboxylic acid ethyl ester (Table 2, entry 8). mp: $254-255^{\circ} \mathrm{C}$; IR $\left(\mathrm{KBr}, \mathrm{cm}^{-1}\right)$ 3286, 3212, 3080, 2963, 1695, 1615, 1498. ${ }^{1} \mathrm{H}$ NMR (400 MHz, $\mathrm{CDCl}_{3}$ ): $\delta 0.95$ (s, 3H), 0.98 (s, 3H), 1.20 (t, $\left.J=7.2 \mathrm{~Hz}, 3 \mathrm{H}\right)$, 2.15-2.36 (m, 4H), 2.40 (s, 3H), 3.75 (s, 3H), 4.05 (q, $J=$ 7.2, 2H), 5.01 (s, 1H), 5.94 (brs, $1 \mathrm{H}, \mathrm{NH}), 6.70$ (d, $J=8 \mathrm{~Hz}$, 2H), 7.20 (d, $J=8 \mathrm{~Hz}, 2 \mathrm{H}) ;{ }^{13} \mathrm{C}$ NMR $\left(100 \mathrm{MHz}, \mathrm{CDCl}_{3}\right): \delta$ $14.24,19.50,27.20,29.43,32.75,35.67,41.16,50.66$, $55.13,59.83,106.45,112.45,113.24,128.90,139.53$, 142.90, 147.80, 157.51, 167.5, 195.52.

4-(4-Methyl-phenyl)-2,7,7-trimethyl-5-oxo-1,4,4a,5,6,7,8, 8aoctahydro-quinoline-3-carboxylic acid ethyl ester (Table 2, entry 12). mp: 261-262 ${ }^{\circ} \mathrm{C}$; IR ( $\left.\mathrm{KBr}, \mathrm{cm}^{-1}\right)$ 3275, 3207, 3085, 2963, 1700, 1610, 1494. ${ }^{1} \mathrm{H}$ NMR (400 MHz, $\left.\mathrm{CDCl}_{3}\right)$ : $\delta 0.96(\mathrm{~s}, 3 \mathrm{H}), 1.08$ (s, 3H), 1.22 (t, $J=7.2 \mathrm{~Hz}, 3 \mathrm{H})$, 2.14-2.36 (m, 10H), 4.05-4.10 (m, 2H), 5.02 (s, 1H), 6.20 (brs, $1 \mathrm{H}, \mathrm{NH}), 7.01$ (d, $J=7.8 \mathrm{~Hz}, 2 \mathrm{H}), 7.15$ (d, $J=7.8 \mathrm{~Hz}$, $2 \mathrm{H}) ;{ }^{13} \mathrm{C}$ NMR (100 MHz, $\mathrm{CDCl}_{3}$ ): $\delta$ 14.22, 19.40, 21.05, 27.23, 29.42, 32.72, 36.08, 41.10, 50.73, 59.83, 106.25, $112.30,127.90,128.61,135.40,143.40,144.15,148.15$, 167.53, 195.64 .

\section{Results and discussion}

Nano sized titanium dioxide was prepared by a sol-gel method using titanium tetrachloride and ethanol as reported in the literature [34]. The results indicated that the surface area is $51.859 \mathrm{~m}^{2} / \mathrm{g}$ for the prepared titanium dioxide. This corresponds to $18.94 \mathrm{~nm}$ in size based on a calculation assuming a spherical shape for the catalyst particles.

The XRD pattern showed the characteristic peak located at $25.34^{\circ}$. Figure 1 shows the XRD peaks associated with the (101), (004), (200), (105), (211), and (204) reflections for anatase which is in agreement with the reported data [35]. Based on the Scherrer formula the crystallite diameters are calculated to be $10 \mathrm{~nm}$ from the half-height width of $2^{\circ}$ of the peak at $25.34^{\circ}$ for this sample.

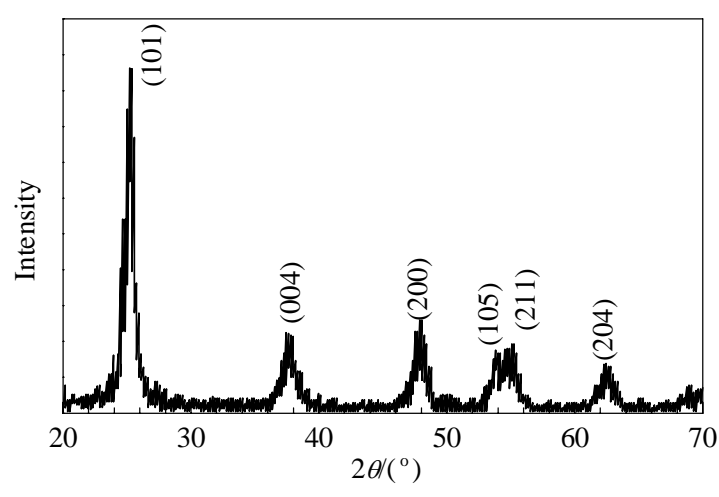

Fig. 1. XRD pattern from pure $\mathrm{TiO}_{2}$.

The difference in particle size resulting from the specific surface area measurement and the XRD diffraction pattern is due to the difference in the assumption of the particle shape i.e. a spherical shape is assumed for the BET analysis while the XRD analysis is based on the anatase phase. The SEM image of the morphology shows that the particles are approximately $29 \mathrm{~nm}$ in size, and they agglomerate (Fig. 2).

The AFM image of the pure nano titanium dioxide shows that the particles are approximately $28 \mathrm{~nm}$ in size (Fig. 3). These combined results demonstrate the formation of single-phase anatase [34].

Initially, we examined the treatment of benzaldehyde and ammonium acetate with two equivalent amounts of ethyl

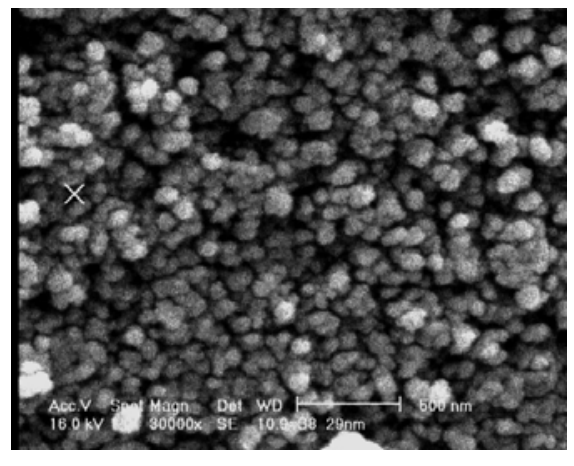

Fig. 2. SEM image of the synthesised $\mathrm{TiO}_{2}$.

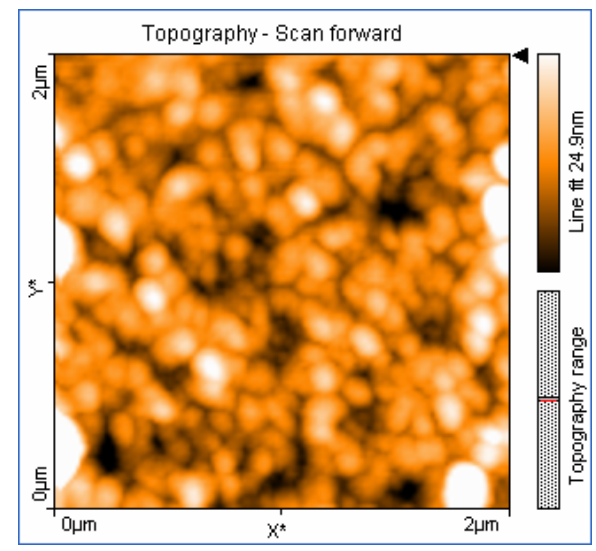

Fig. 3. AFM image of pure $\mathrm{TiO}_{2}$. 
acetoacetate as a model reaction in EtOH using different catalysts in order to determine the efficiency of the titanium dioxide nanoparticles in this reaction.

Various catalysts were tested and representative results are listed in Table 1. It turned out that titanium dioxide nanoparticles gave better results than titanium dioxide and the other catalysts listed in Table 1 in terms of yield and reaction rate.

As shown in Table 1, we first assayed Amberlyst-15, sulfamic acid, phenylphosphonic acid, phenylphosphinic acid, $\beta$-CD-OSO ${ }_{2} \mathrm{H}$, and silica sulfuric acid as catalysts, but the yields obtained were only moderate, even with high catalyst loadings (Table 1, entries 1-7). The best result was obtained with titanium dioxide nanoparticles in ethanol with $92 \%$ isolated yield (Table 1, entry 8 ). The high efficiency of the $\mathrm{TiO}_{2}$ nanoparticles may be due to their high surface area compared with the other catalysts.

Table 1 Comparison of catalytic activity of titanium dioxide nanoparticles with some other catalysts

\begin{tabular}{cccc}
\hline Entry & Catalyst & Time (h) & Yield $^{\mathrm{a}}(\%)$ \\
\hline 1 & sulfamic acid & 6 & 30 \\
2 & Amberlyst-15 $(10 \%, w / w)$ & 10 & 30 \\
3 & $\beta$-CD-OSO ${ }_{2} \mathrm{H}$ & 12 & 50 \\
4 & $\mathrm{C}_{6} \mathrm{H}_{5} \mathrm{PO}(\mathrm{OH})_{2}$ & 8 & 45 \\
5 & $\mathrm{C}_{6} \mathrm{H}_{5} \mathrm{PO}_{2} \mathrm{H}_{2}$ & 8 & 45 \\
6 & $\mathrm{H}_{2} \mathrm{SO}_{4} / \mathrm{SiO}_{2}(10 \%, w / w)$ & 8 & 50 \\
7 & $\mathrm{TiO}_{2}$ & 6 & 75 \\
8 & titanium dioxide nanoparticles & 1.75 & 92 \\
9 & none & 12 & 30 \\
\hline
\end{tabular}

${ }^{\mathrm{a}}$ Yield refers to isolated products.

An increase in the amount of the catalyst from $10 \mathrm{~mol} \%$ to $20 \mathrm{~mol} \%$ did not improve the yield to a greater extent and lowering the catalyst loading from $10 \mathrm{~mol} \%$ to $5 \mathrm{~mol} \%$ and decreasing the temperature from 80 to $40{ }^{\circ} \mathrm{C}$ reduced the yield and increased the reaction time.

To demonstrate the efficiency of the catalyst a blank reaction was carried out in the absence of catalyst under refluxing EtOH. After $12 \mathrm{~h}$ stirring, classical work-up and recrystallization from ethanol, only $30 \%$ of the product was isolated (Table 1, entry 9).

We then continued to optimize the model reaction mentioned above by determining the efficiency of several classical solvents which were chosen as the medium for comparison (Table 2). In each case, the substrates were mixed together with $10 \mathrm{~mol} \%$ of titanium dioxide nanoparticles and agitated with $2 \mathrm{ml}$ solvent.

It was found that, $\mathrm{CH}_{2} \mathrm{Cl}_{2}, \mathrm{CH}_{3} \mathrm{CN}$, toluene, $\mathrm{H}_{2} \mathrm{O}$, and the solventless system were unfavorable for the formation of the product (Table 2, entries 1-6)

The effect of temperature was also studied by carrying
Table 2 The efficiency of several classical solvents

\begin{tabular}{ccccc}
\hline Entry & Solvent & Temperature $\left({ }^{\circ} \mathrm{C}\right)$ & Time (h) & Yield $^{\mathrm{a}}(\%)$ \\
\hline 1 & - & 25 & 6 & 60 \\
2 & - & 80 & 6 & 68 \\
3 & $\mathrm{CH}_{2} \mathrm{Cl}_{2}$ & reflux & 6 & 35 \\
4 & $\mathrm{CH}_{3} \mathrm{CN}$ & reflux & 6 & 45 \\
5 & toluene & reflux & 6 & 50 \\
6 & $\mathrm{H}_{2} \mathrm{O}$ & reflux & 6 & 30 \\
7 & $\mathrm{H}_{2} \mathrm{O}+\mathrm{EtOH}$ & reflux & 6 & 42 \\
8 & EtOH & reflux & 1.75 & 92 \\
9 & EtOH & 40 & 6 & 78 \\
10 & EtOH & 25 & 4 & 45 \\
\hline
\end{tabular}

${ }^{\mathrm{a}}$ Yield refers to isolated products.

out the model reaction at different temperatures (Table 2, entries 8-10). It was observed that the product was obtained in excellent yield if the reaction was carried out in EtOH at reflux temperature (Table 2, entry 8).

We evaluated the efficacy and applicability of our protocol for the three component condensation using a variety of structurally distinct aldehydes. Various aliphatic, aromatic, and heterocyclic aldehydes underwent smooth cyclocondensation in good to excellent yields and the results are depicted in Table 3. As shown in this Table, aromatic aldehydes bearing electron-deficient or electron-rich substituents on the aromatic ring as well as aliphatic aldehydes afforded the desired 1,4-DHP in excellent yields (Table 3, entries 1-15).

After successfully synthesizing a series of Hantzsch esters in excellent yields, we turned our attention towards the four component reaction of cyclic 1,3-diketone, aldehyde, acetoacetic ester, and ammonium acetate to prepare the

Table 3 Titanium dioxide nanoparticle-catalyzed synthesis of 1,4-DHPs via Hantzsch reaction

\begin{tabular}{|c|c|c|c|c|c|}
\hline \multirow{2}{*}{ Entry } & \multirow{2}{*}{$\mathrm{R}$} & \multirow{2}{*}{$\begin{array}{c}\text { Time } \\
\text { (h) }\end{array}$} & \multirow{2}{*}{$\begin{array}{c}\text { Yield }^{\mathrm{a}} \\
(\%)\end{array}$} & \multicolumn{2}{|c|}{$\mathrm{mp}\left({ }^{\circ} \mathrm{C}\right)$} \\
\hline & & & & Found & Reported \\
\hline 1 & $\mathrm{C}_{6} \mathrm{H}_{5}$ & 1.75 & 92 & $157-158$ & $158-160$ [36] \\
\hline 2 & 4- $\mathrm{Br}-\mathrm{C}_{6} \mathrm{H}_{4}$ & 1.75 & 89 & $160-163$ & $162-164$ [37] \\
\hline 3 & $4-\mathrm{Cl}-\mathrm{C}_{6} \mathrm{H}_{4}$ & 2 & 90 & $145-147$ & $147-148$ [36] \\
\hline 4 & $3-\mathrm{Cl}-\mathrm{C}_{6} \mathrm{H}_{4}$ & 2 & 86 & $140-142$ & $141-143$ [38] \\
\hline 5 & 2-Cl- $\mathrm{C}_{6} \mathrm{H}_{4}$ & 2 & 80 & $82-84$ & 83-85 [39] \\
\hline 6 & $4-\mathrm{O}_{2} \mathrm{~N}-\mathrm{C}_{6} \mathrm{H}_{4}$ & 2 & 87 & $128-130$ & $129-131$ [36] \\
\hline 7 & $4-\mathrm{MeO}-\mathrm{C}_{6} \mathrm{H}_{4}$ & 3 & 81 & $160-162$ & $161-163$ [36] \\
\hline 8 & $4-\mathrm{HO}-\mathrm{C}_{6} \mathrm{H}_{4}$ & 2 & 93 & $225-226$ & $227-228$ [40] \\
\hline 9 & 4- $\mathrm{CH}_{3}-\mathrm{C}_{6} \mathrm{H}_{4}$ & 1.75 & 90 & 135-138 & 135-137 [7] \\
\hline 10 & $4-\mathrm{CN}-\mathrm{C}_{6} \mathrm{H}_{4}$ & 2 & 90 & $141-142$ & - \\
\hline 11 & $\mathrm{C}_{6} \mathrm{H}_{5}-\mathrm{CH}=\mathrm{CH}$ & 2 & 86 & $146-148$ & $141-143$ [39] \\
\hline 12 & $\mathrm{C}_{7} \mathrm{H}_{5} \mathrm{O}$ & 2 & 92 & $280-283$ & - \\
\hline 13 & 2-furyl & 3.75 & 50 & 159-162 & $160-161$ [36] \\
\hline 14 & 2-thienyl & 4 & 90 & $170-172$ & $171-173$ [36] \\
\hline 15 & $\mathrm{C}_{6} \mathrm{H}_{12} \mathrm{O}$ & 1.5 & 95 & - & [29] \\
\hline
\end{tabular}

${ }^{\mathrm{a}}$ Yield refers to isolated products. 
Table 4 Titanium dioxide nanoparticle-catalyzed synthesis of polyhydroquinoline derivatives via Hantzsch reaction

\begin{tabular}{|c|c|c|c|c|c|}
\hline \multirow{2}{*}{ Entry } & \multirow{2}{*}{$\mathrm{R}$} & \multirow{2}{*}{$\begin{array}{l}\text { Time } \\
\text { (min) }\end{array}$} & \multirow{2}{*}{$\begin{array}{c}\text { Yield }^{\mathrm{a}} \\
(\%)\end{array}$} & \multicolumn{2}{|c|}{$\mathrm{mp}\left({ }^{\circ} \mathrm{C}\right)$} \\
\hline & & & & Found & Reported \\
\hline 1 & $\mathrm{C}_{6} \mathrm{H}_{5}$ & 30 & 96 & $201-203$ & $202-204$ [28] \\
\hline 2 & 4- $\mathrm{Br}-\mathrm{C}_{6} \mathrm{H}_{4}$ & 30 & 94 & $252-253$ & $253-255$ [28] \\
\hline 3 & $3-\mathrm{Br}-\mathrm{C}_{6} \mathrm{H}_{4}$ & 30 & 90 & 235 & $235-236$ [28] \\
\hline 4 & $4-\mathrm{Cl}-\mathrm{C}_{6} \mathrm{H}_{4}$ & 30 & 92 & $244-245$ & $244-246[41]$ \\
\hline 5 & $2-\mathrm{Cl}-\mathrm{C}_{6} \mathrm{H}_{4}$ & 45 & 90 & $208-210$ & $209-211$ [42] \\
\hline 6 & $3-\mathrm{Cl}-\mathrm{C}_{6} \mathrm{H}_{4}$ & 45 & 90 & $231-234$ & $234-235$ [24] \\
\hline 7 & 4- $\left(\mathrm{CH}_{3}\right)_{2} \mathrm{~N}-\mathrm{C}_{6} \mathrm{H}_{4}$ & 40 & 80 & $230-231$ & $229-231$ [28] \\
\hline 8 & $4-\mathrm{MeO}-\mathrm{C}_{6} \mathrm{H}_{4}$ & 30 & 93 & $254-255$ & $257-259$ [28] \\
\hline 9 & $4-\mathrm{F}-\mathrm{C}_{6} \mathrm{H}_{4}$ & 30 & 90 & $182-184$ & $184-186$ [28] \\
\hline 10 & $4-\mathrm{O}_{2} \mathrm{~N}-\mathrm{C}_{6} \mathrm{H}_{4}$ & 25 & 88 & $241-243$ & $245-246$ [42] \\
\hline 11 & $2-\mathrm{O}_{2} \mathrm{~N}-\mathrm{C}_{6} \mathrm{H}_{4}$ & 30 & 82 & $210-215$ & $208-211$ [43] \\
\hline 12 & $4-\mathrm{CH}_{3}-\mathrm{C}_{6} \mathrm{H}_{4}$ & 40 & 92 & $261-262$ & $260-261$ [28] \\
\hline 13 & 4- $\mathrm{HO}-\mathrm{C}_{6} \mathrm{H}_{4}$ & 30 & 86 & $232-233$ & $232-234$ [28] \\
\hline 14 & $\mathrm{C}_{6} \mathrm{H}_{5}-\mathrm{CH}=\mathrm{CH}$ & 40 & 90 & 204-207 & 204-206 [41] \\
\hline 15 & 2-Thienyl & 30 & 89 & $241-243$ & $241-244$ [42] \\
\hline 16 & 3-Thienyl & 30 & 91 & $250-253$ & $248-250$ [28] \\
\hline 17 & 2-Furyl & 30 & 90 & $245-248$ & $246-248$ [28] \\
\hline 18 & 3-Pyridyl & 40 & 89 & $65-66$ & $66-67$ [28] \\
\hline 19 & $\mathrm{C}_{4} \mathrm{H}_{8} \mathrm{O}$ & 40 & 84 & $145-146$ & $147-148$ [28] \\
\hline
\end{tabular}

${ }^{a}$ Yield refers to isolated products.

polyhydroquinoline derivatives under similar reaction conditions.

In this regard, aliphatic, aromatic, heterocyclic, and conjugated aldehydes reacted smoothly under similar conditions to give the corresponding polyhydroquinolines in high yields as summarized in Table 4.

It can be seen that the variations in the yields were small and both electron-rich and electron-deficient aldehydes as well as heterocyclic ones worked well, giving good to excellent yields of the substituted polyhydroquinoline derivatives (Table 4, entries 1-19).

In view of environmental friendly methodologies, the advantages of the used catalyst will clearly be higher if the catalyst can be recovered and reused. So, to explore the recyclability of the catalyst, the titanium dioxide nanoparticles were recovered from the reaction mixture in the model reaction by a simple work up and used in six successive runs without significant loss of their catalytic activity (Table $5)$.

Table 5 Recyclability of the catalyst in the model reaction

\begin{tabular}{ccc}
\hline Entry & Cycle & Yield $^{\mathrm{a}}(\%)$ \\
\hline 1 & 1 & 92 \\
2 & 2 & 90 \\
3 & 3 & 87 \\
4 & 4 & 87 \\
5 & 5 & 85 \\
6 & 6 & 87 \\
\hline
\end{tabular}

${ }^{\mathrm{a}}$ Yield refers to isolated products.

\section{Conclusions}

We have developed a simple and efficient method for the synthesis of 1,4-DHPs and polyhydroquinolines using titanium dioxide nanoparticles as catalyst in EtOH. This method offers several advantages including high yield, short reaction time, simple work-up procedure with the avoidance of discharging harmful organic solvents, ease of separation and recyclability of the catalyst.

\section{Acknowledgments}

We are thankful to the Research Council of Mazandaran University, Gorgan Medical University and Islamic Azad University-Ayatollah Amoli Branch for the partial support of this work.

\section{References}

1 Martins M A P, Frizzo C P, Moreira D N, Buriol L, Machado P. Chem Rev, 2009, 109: 4140

2 Saushins A, Duburs G. Heterocycles, 1988, 27: 269

3 Mager P P, Coburn R A, Solo A J, Triggle D J, Rothe H. Drug Des Discovery, 1992, 8: 273

4 Manhold R, Jablonka B, Voigdt W, Schoenfinger K, Schravan E. Eur J Med Chem, 1992, 27: 229

5 Hantzsch A. Justus Liebigs Ann Chem, 1882, 215: 1

6 Evdokimov N M, Magedov I V, Kireev A S, Kornienko A. Org Lett, 2006, 8: 899

7 Khadikar B M, Gaikar V G, Chitnavis A A. Tetrahedron Lett, 1995, 36: 8083

8 Ohberg L, Westman J. Synlett, 2001: 1296

9 Agarwal A, Chauhan P M S. Tetrahedron Lett, 2005, 46: 1345

10 Ji S J, Jiang Z Q, Lu J, Loh T P. Synlett, 2004: 831

11 Phillips A P. J Am Chem Soc, 1949, 71: 4003

12 Anderson A G, Berkelhammer G. J Am Chem Soc, 1958, 80: 992

13 Singh H S, Chimni S S, Kumar S. Tetrahedron, 1995, 51: 12775

14 Breitenbucher J G, Figliozzi G. Tetrahedron Lett, 2000, 41: 4311

15 Liang J C, Yeh J L, Wang C S, Liou S F, Tasi C H, Chen I J. Bioorg Med Chem, 2002, 10: 719

16 Miri R, Niknahad H, Vesal G, Shafiee A. Farmaco, 2002, 57: 123

17 Dondoni A, Massi A, Minghini E, Sabbatini S, Bertoasi V. $J$ Org Chem, 2003, 68: 6172

18 Dondoni A, Massi A, Minghini E, Bertoasi V. Tetrahedron, 2004, 60: 2311

19 Sabitha G, Reddy G S K K, Reddy C S, Yadav J S. Tetrahedron Lett, 2003, 44: 4129

20 Babu G, Perumal P T. Aldrichim Acta, 2000, 33: 16

21 Ko S, Sastry M N V, Lin C, Yao C F. Tetrahedron Lett, 2005, 46: 5771 
22 Adharvana Chari M, Syamasundar K. Catal Commun, 2005, 6: 624

23 Maheswara M, Siddaiah V, Rao Y K, Tzeng Y M, Sridhar C. $J$ Mol Catal A, 2006, 260: 179

24 Ko S, Yao C F. Tetrahedron, 2006, 62: 7293

25 Perozo-Rondon E, Calvino-Casilda V, Martin-Aranda R M, Casal B, Duran-Valle C J, Rojas-Cervantes M L. Appl Surf Sci, 2006, 252: 6080

26 Lee J H. Tetrahedron Lett, 2005, 46: 7329

27 Kumar A, Maurya R A. Tetrahedron, 2007, 63: 1946

28 Wang L M, Sheng J, Zhang L, Han J W, Fan Z Y, Tian H, Qian C T. Tetrahedron, 2005, 61: 1539

29 Safari J, Banitaba S H, Dehghan Khalili S. Chin J Catal, 2011, 32: 1850

30 Heydari A, Khaksar S, Tajbakhsh M, Bijanzadeh H R. $J$ Fluorine Chem, 2009, 130: 609

31 Baghbanian S M, Khaksar S, Vahdat S M, Farhang M, Tajbakhsh M. Chin Chem Lett, 2010, 21: 563

32 Tajbakhsh M, Heydari A, Alinezhad H, Ghanei M, Khaksar S. Synthesis, 2008: 352
33 Khaksar S, Heydari A, Tajbakhsh M, Bijanzadeh H R. J Fluorine Chem, 2010, 131: 106

34 Li G, Li L, Boerio-Goates J, Woodfield B F J. J Am Chem Soc, 2005, 127: 8659

35 Tong T, Zhang J, Tian B, Chen F, He D. Mater Lett, 2008, 62: 2970

36 Eynde J J V, Delfosse F, Mayence A, van Haverbeke Y. Tetrahedron, 1995, 51: 6511

37 Debache A, Ghalem W, Boulcina R, Belfaitah A, Rhouati S, Carboni B. Tetrahedron Lett, 2009, 50: 5248

38 Shaabani A, Rezayan A H, Rahmati A. Monatsh Chem, 2006, 137: 77

39 Wang S X, Li Z Y, Zhang J C, Li J L. Ultrason Sonochem, 2009, 15: 677

40 Sridhar R, Perumal P T. Tetrahedron, 2005, 61: 2465

41 Reddy C S, Raghu M. Chin Chem Lett, 2008, 19: 775

42 Kumar S, Sharma P, Kapoor K K, Hundal M S. Tetrahedron, 2008, 64: 536

43 Karade N N, Budhewar V H, Shinde S V, Jadhav W N. Lett Org Chem, 2007, 4: 16 